\title{
IMPROVING THE STUDENTS' VOCABULARY SKILL THROUGH REAL OBJECT MEDIA ON THE SECOND SEMESTER STUDENTS OF ACADEMIC YEAR 2017/2018
}

\author{
Aflina \\ Department of English Studies, Universitas Harapan Medan, North Sumatera \\ Indonesia \\ alinaarifin@gmail.com
}

\begin{abstract}
This study is intended to investigate whether Using Real Object Media can significantly improving the Students' Vocabulary through Real Object Media on the second semester students of academic year 2017/2018. The technique of the research was Classroom Action Research. Subject of the study on the second semester students of academic year 2017/2018 which consisted of 36 students. The instrument applied in collecting the data was multiple choice test, which consisted of 10 tests. Besides multiple choice test, the data was collected from Diary Notes, Interview and Observation sheet to identify what happened in the classroom while teaching learning process ran. After analyzing the data, it was obtained that the data was 85, 43. It could be seen that the mean of the students increased from 58, 57 to 85, 43 and the total score increased form 2050 to 2990. It means that Real Object Media can improve the Students' Vocabulary
\end{abstract}

\section{Key Words: Improving, Vocabulary Skill, Real Object Media}

\section{INTRODUCTION}

Language is tool of communication used to communicate between two or more people in carrying out their daily activities and has main role to make people understand each other. The function of language is not only for a communication but also for culture transfer. English is an international language which was taught in the most country in the world. Almost the people of the earth know English.

In Indonesia, English is regarded as the first foreign language, it is important for developing and applying science and technology, as well as for increasing international cooperation and relationship. It has also become a part of the curriculum in the schools.

Based on National Education Curriculum in 2006 called Educational Unit level Curriculum, the Indonesian government gives the autonomy to every school to arrange and control it in teaching learning activity. There are four skills that should be mastered by the students; they are listening, speaking, reading, and writing including vocabulary.

In the Educational Unit Level Curriculum, the first year students of Senior High School are expected to be able to be competent in vocabulary. Vocabulary is one important aspects has a position in the four language skills, without vocabulary nothing can be conveyed. Only with sufficient vocabulary the students can express their ideas effectively, and understand the language task and foreign language conversation. If the students have limited vocabulary they will have difficulties in learning and understanding the foreign language.

Based on the preliminary observation that has conducted on the second semester students of academic year 2017/2018. The researcher found on the second semester students of academic year 2017/2018 students of that school have a low ability in English vocabulary. Almost all the students did not know the meaning of words and they assume that memorizing the new word is a difficult task. The researcher can conclude it based on the result of the interview and the result of the preliminary that was conducted on that school.

The researcher interviewed both the English teacher and the students, and based on the information collected from the interview both the teacher and the students believed that the students have a problem in recalling English vocabulary. In addition the result of the students' daily test showed that the mean score of the students was only 5,0 - 6,00 in English teacher's document. Moreover, if it is compared with the minimum passing grade for English is 65. 
Vocabulary is one of the essential aspects in studying English as foreign language. Without having sufficient number of English vocabulary the students will not be able to communicate correctly in English. There are some experts who believe that vocabulary is very important in studying a language, especially in foreign language. In order to be able to communicate in natural way in English people need to master 1000-1200 words.

From the observation conducted by the researcher, and also teacher must choose a suitable teaching ways in teaching vocabulary. Nowadays, in teaching vocabulary, usually the teacher orientates to thestudents' English books. It was not effective to improve his student's vocabulary. The teachers only taught the material and forced their students to memorize the new vocabulary with always open the dictionary. Consequently, the students' vocabulary is low. In order to solve the problem above, using Real Object Media will be one of Medias that the researcher recommends to be used. It can make the students add and develop their new words. Based on the reason, the writer would like to conduct a research entitled 'improving the students' vocabulary skill through Real Object Media on the second semester students of academic year 2017/2018 So, to build students' understanding and ability in English, the writer is trying to use equipment in the classroom to increase their vocabulary because equipment is close and familiar with the students. It can make them enjoyable in the class.

\section{OBJECTIVE OF THE RESEARCH}

How real object media can improve students vocabulary skill?

\section{RESEARCH METHOD}

This research use survey method on the second semester students, so that the sample is taken by random purposive, real object media strategy with audio Visual media become experiment as many as 36 students.

\section{REVIEW OF LITERATURE}

In the past, vocabulary teaching and learning were often given little priority in second language programs, but recently there has been a renewed interest in the nature of vocabulary.

Although vocabulary is the one that is emphasized, it does not mean other kinds of language components-grammar and pronunciation-are less important. All of these aspects are learned together, because they are attached one to another. Vocabulary is extremely large and also varies. Nobody ever learned all the words in any language but they can enlarge the number of words they have. Larger vocabulary the students have can help them in many ways, students' reading ability and writing ability will improve as they learn new words, and the more words they know the better their chance will be to do well on the vocabulary questions, in the school. Therefore, it is highly essential for English teacher to help their students in mastering vocabulary along with grammar and pronunciations.

Learning vocabulary is very important part of learning English, vocabulary is also a vital thing that should be mastered in order to understand collocation competence with the vocabulary they have already got. For advance learners he also suggests building on what they already know, using better strategies and increasing the number of items they meet outside the classroom.

\section{THE RESEARCH METHOD}

This research will be conducted to on the second semester students of academic year 2017/2018 based on the preliminary observation show that those students have a problem in English Vocabulary. They cannot memorize the English words that have been thought by the teacher easily. Based on the problem the researcher will try to find the solution for the students so they can memorize the English words easily by changing the teaching technique with Real Object Media. There are 36 students in that class. Since this research is a kind of Class Action Research, because it is one of ways suitable for learning process, exactly not only for the teachers, but also the students have more deep understanding about the material. Action research is an observation of an activity that appears consciously in a class. The researcher takes on the second semester students of academic year 2017/2018 as the sample. 


\section{THE MEANING OF VOCABULARY}

Good mastery of vocabulary is important foranyone who learns the language used in listening, speaking, writing, andreading besides grammar. The students who learns of the foreign language will speakfluently and accurately, write easily, or understand what he or she reads orhears if he or she has enough vocabulary and has a capability of using itaccuratel. Vocabulary is considered as the most important part in learning alanguage. It is impossible for the students to read, write and speak a foreignlanguage without having enough knowledge of the vocabulary. Learning thenew vocabulary does not only mean memorizing the form of the word but alsounderstand the meaning.

A good vocabulary increases your ability to understand reading material and to express yourself in speaking and in writing. In the same way, being a good speller will make it easier for others to understand what you are trying to say. Without a broad vocabulary, your ability to learn is limited. The good news is that vocabulary and spelling skills can be developed with practice.

In some literature, I found the meaning of vocabulary. There are some definitions of vocabulary. Webster (1972:2046) states that vocabulary is:

a. A list of words, and sometime phrases, usually arranged in alphabetical order and defined; a dictionary, glossary or lexicon.

b. All the words of a language

c. All the words used by a particular person, class, profession, etc.: sometimes, all the words recognized and understood by a particular person, although not necessarily used by him (in full, passive vocabulary).

d. They love to play and learn best when they enjoy themselves. But they also take themselves seriously and like to think that what they are doing is real work.

e. They are enthusiastic and positive about learning.

f. They rely on the spoken words as well as the physical world to convey and understanding meaning.

g. They are able to work with other and learning from other.

h. Their own understanding comes through eyes, hands and ears. The physical world is dominant all times.

i. They have very short attention and concentration.

\section{LEARNING MEDIA}

Media is a tool that used to deliver message and information from the sender to the receiver of the message. Media is everything that used convey information (AECT,1997). It is realized that the media is very important components in a process of communication.

Based on the defined above it can be concluded that the media has important role of sending a message or information from the sender to the receiver. The definition of instructional media is everything that can bring information or message and knowledge in under way instruction between the teacher and the students.

Media are generally defined as the mean by which information is conveyed from one place to another. In the past century, various forms of media have been used to convey instruction and to support learning. Examples of instructional media conclude:

* Traditional media, it means of delivering instruction by using chalkboards, textbooks, overhead projectors, and teachers.

* Mass media such as newspaper, movies, radio, and television, and the newer is "electronic" instructional media such as computers, interactive video, and multimedia systems.

As the carries of the message, media helps teachers convey the teaching materials clearly and for the students to understand easily.

\section{TYPES OF LEARNING MEDIA}

Media is very important in teaching and learning process because it can make the teacher is easy to deliver the material. According to Briggs in Learning Media Books by Dr. Arief S. Sadiman, M. Sc. (2007:23) Learning media is divided in to thirteen kinds namely : object (real object), model, direct sound, audio recorder, print media, programmed learning, whiteboard, media transparency, movie sets, the movie frames, the movie, television and picture. Media can be divided into four types: 
a. Visual media

The types of media used only rely on the sense of vision from the learner. Some of the visual media, like: (1) the print media such as books, maps, pictures, posters; (2) models and prototypes such as a globe of the earth and (3) the reality media in surrounding nature.

b. Audio media

Audio media is a type of media used in the learning process by involving only the sense of hearing learners. The examples commonly used are tape recorders, radios, and CD player.

c. Audio visual media

Audio visual media is the type of media used in the learning activities involving hearing and vision as well as in a process or activity. The message and information submitted can be channeled through this media can be either verbal and non-verbal messages that rely on both vision and hearing. Some examples of audio-visual media is film, video, TV programs.

d. Multimedia

Multimedia is media that involves several types of media and equipment are integrated in a process or learning activities. Multimedia learning involves the senses of vision and hearing through the media text, visual silence, visual motion, and audio and computer-based interactive media and information technology for example interactive computer applications and non-interactive.

\section{RESULTS AND DISCUSSION}

The data in this research was taken from Diary Notes, Interview, Observation sheet and Vocabulary Test (Multiple Choice). To collect the data, the researcher did observation in the classroom by interviewing the teacher and the students. Then, the writer consulted with the teacher about what they would do.

The main focus of this research was actions which were done in two cycles. Every cycle and four phases namely planning, acting, observing, and reflecting. The research was done on the second semester students of academic year 2017/2018. here were 35 students which consist of 16 male and 20 female students as subject of the research. They were never absent during the writer conducting the research from the first meeting until the last meeting.

The result showed the improvement of the students' score from the Preliminary test to the Test of cycle I, Test of cycle I to Test of cycle II. When the first test (Preliminary Test) was conducted to the students there were only or 11 Students who got the score above 65. In the second test (Test of cycle I) which was conducted to the students who got the score above 65 . It meant there was an improvement of students in their vocabulary about 26 students compared with conducted to the students in cycle II of action research, there were only or 36 Students who got the score above 65 . It meant there was an improvement of students in their vocabulary about $100 \%$ compared with the second test (Test of cycle I) therefore, it could be concluded that the real thing media in contextual teaching learning could improve students' vocabulary achievement.

\section{CONCLUSION}

After analyzing the data, it was found that the students' score increased from Preliminary Test to Test cycle I until Test of cycle II, it can be concluded that.

a. The applied of Real Object Media was improved the students' vocabulary skill, it could be seen from improvement of mean of students' score namely, the mean of Preliminary Test $(58,35)$ improved to the mean of Test in cycle I $(70,05)$ and to the mean of Test in cycle II $(85,50)$

b. The percentage of the students' vocabulary achievement showed improvement of students' vocabulary achievement by using Real Object Media. In preliminary test there were 32,45 or twelve students who got the score above 65 . In the test of cycle I there were 71,55 or twenty two students who got the score above 65 . In the test of cycle II there were $100 \%$ or thirty five students who got the score above 65. It was also proved by the diary notes, observation sheet's result, interview sheet and photography evidence result which indicated improvement in teaching learning process from cycle I to cycle II. Based on the result of the data, the conclusion was that teaching through real object media in contextual teaching learning could improve students vocabulary achievement. 


\section{REFERENCES}

Arikunto, Suharsimi. (1993). Procedure PenelitianSuatuPendekatanPraktek. Jakarta: PT. RinekaCipta

Arikunto, 2006.Penelitian Tindak Kelas.PT Bumi Aksara. Jakarta Indonesia.

BahleuwiAjie. 2007. Instant Vocabulary. Jakarta Leaysamedia.

Finnochiaro, Mary. 1974. English as a Second Language: From Theory topractice. London: Regents PublishingCompany.

Franklin, Meikle.2001. Vocabulary in Context.

Heinich, Molenda, 1982, Instructional Media, New York.

Hughes, Arthur. 1993. Testing for Language Teacher. Glasgow: CambridgeUniversity Press.

Jeremy Harmer, Thomburry. 2001. How to Teach Vocabulary. Wesley Longman

Jhon M.Echols.2002. Kamus Inggris-Indonesia

Marianne Celce and Murcia Elite Olshtain, 2000.Discourse and Context in LanguageTeaching: A Guide for Language Teachers, (New York: CambridgeUniversity Press,

MarzuqAchmad. 2004. Smart Vocabulary. Surabaya: Indah Surabaya

Sadiman, Arif S (ddk). 2007. Media Pendidikan. Jakarta; PT.RajaGrafindoPersada.

Tony Dudly-Evans and Manggie Jo St Jhon. (2005). Description of VocabularyCambridge. University Press.

Wallace, J. Michael. 1982. Teaching Vocabulary. London: Biddles Ltd, Guldford.

English Club. 1997-2013. What is Vocabulary?http://www.EnglishClub.com

What is Vocabulary. Accessed on Tuesday, December 18,2012

www.englishforums.com/English/MeaningWordVocabulary

James W. Bron (1977). Media Model Sebagai Sumber Belajar. (online).

Tersedia:

http://repository.upi.edu/operator/uploads/s_ktp_022192_chapter.pdf ( December 15, 2014)

http://googlesearch;vocabulary.November.2014

http://googlesearch;equipment.November.2014

http://googlesearch;advantageanddisadvantagerealobjectmedia.December,2014

http://googlesearch;realobjectmedia.December.2014 